\title{
РОЗВИТОК ТУРИСТИЧНО-РЕКРЕАЦІЙНОГО КОМПЛЕКСУ В УМОВАХ СТАЛОГО ЗРОСТАННЯ ЕКОНОМІКИ
}

\section{DEVELOPMENT OF TOURIST AND RECREATIONAL COMPLEX IN CONDITIONS OF SUSTAINABLE GROWTH OF ECONOMY}

\author{
Пригара Ольга Василівна \\ кандидат біологічних наук, доцент, \\ Ужгородський національний університет \\ ORCID: https://orcid.org/0000-0003-3433-7173 \\ Брик Степан Дмитрович \\ кандидат географрічних наук, асистент, \\ Чернівецький національний університет імені Юрія Федьковича \\ ORCID: https://orcid.org/0000-0002-2992-1634 \\ Голубець Ірина Миколаївна \\ кандидат культурології, старший викладач, \\ Приватний вищий навчальний заклад \\ «Київський університет культури» \\ ORCID: https://orcid.org/0000-0002-3491-0155 \\ Pryhara Olha \\ Uzhorod National University \\ Bryk Stepan \\ Yuriy Fedkovych Chernivtsi National University \\ Holubets Iryna \\ Private Higher Educational Institution "Kyiv University of Culture"
}

\begin{abstract}
У науковій статті досліджено особливості розвитку туристично-рекреаційного комплексу в умовах сталого зростання економіки України. Встановлено, що туристично-рекреаційний комплекс - це один із ключових видів економічної діяльності в Україні, без якої не можливий сталий розвиток національної економіки. Пандемічні обмеження, спричинені COVID-19, негативно позначились на показниках розвитку туристично-рекреаційного комплексу України. Так, у 2020 році у порівнянні із попередніми роками, а особливо із 2019 роком, суттєво скоротились надходження від подорожей та туризму в національну економіку, i, як наслідок, знизилася частка надходжень від подорожей та туризму у ВВП України. Пандемічні обмеження негативно позначились на залученні капітальних інвестицій у розвиток туристичної діяльності в Україні, а також на стані діяльності колективних засобів розміщування. Тому, з метою зниження наслідків пандемічних обмежень на розвиток туристично-рекреаційного комплексу доцільно впроваджувати заходи мінімізації впливу пандемічних ризиків через спеціально розроблені програми підтримки видів економічної, зокрема туристично-рекреаційної діяльності, як на рівні держави, так і на рівні регіонів чи мікрорівні.
\end{abstract}

Ключові слова: туристично-рекреаційний комплекс, стале зростання, туризм, рекреаційний потенціал, національна економіка.

В научной статье исследованы особенности развития туристическо-рекреационного комплекса в условиях устойчивого роста экономики Украины. Установлено, что туристическо-рекреационный комплекс - это один из ключевых видов экономической деятельности в Украине, без которой невозможно устойчивое развитие национальной экономики. Пандемические ограничения, вызванные пандемией COVID-19, отрицательно влияли на показатели развития туристическо-рекреационного комплекса Украины. Так, в 2020 году по сравнению с предыдущими годами, особенно с 2019 годом, существенно сократились поступления от путешествий и туризма в национальную экономику, и, как следствие, снизилась доля поступлений от путешествий и туриз- 
ма в ВВП Украины. Пандемические ограничения негативно влияли на привлечении капитальных инвестиций в развитие туристической деятельности в Украине, а также на состояние коллективных средств размещения. Поэтому, с целью снижения последствий пандемических ограничений на развитие туристическо-рекреационного комплекса нужно целесообразно внедрять меры по минимизации влияния пандемических рисков через специально разработанные программы поддержки видов экономической, в частности туристическо-рекреационной деятельности, как на уровне государства, так и на уровне регионов или микроуровне.

Ключевые слова: туристическо-рекреационный комплекс, устойчивый рост, туризм, рекреационный потенциал, государственная экономика.

The scientific article investigates the peculiarities of the development of the tourist and recreational complex in the conditions of sustainable growth of the economy of Ukraine. It is established that the tourist and recreational complex is one of the key types of economic activity in Ukraine, without which sustainable development of the national economy is not possible. It has been found that in today's environment, the tourism and recreation industry has been significantly affected by the effects of the COVID-19 pandemic. As a result of this impact, the level of efficiency of tourism and recreational activities has decreased, which has had a negative impact on the path to sustainable economic growth. It is determined that the contribution of the tourist and recreational complex to the GDP is sufficiently conditioned by the development and implementation in practice of state programs aimed at creating favorable conditions for the development of tourism and recreation. It is worth noting that during the studied 2015-2020 the dynamics of development of the tourist and recreational complex was extremely unstable, especially in the last year. The pandemic restrictions caused by the COVID-19 pandemic had a negative impact on the development of Ukraine's tourism and recreation complex. Thus, in 2020, compared to previous years, and especially in 2019 , revenues from travel and tourism to the national economy decreased significantly, and, as a result, the share of revenues from travel and tourism in Ukraine's GDP decreased. Pandemic restrictions have negatively affected the attraction of capital investment in the development of tourism in Ukraine, as well as the state of collective accommodation. Emphasizing the negative consequences, it is worth noting the presence of some negative impact on the national economy from tourism and recreation. Therefore, in order to reduce the impact of pandemic restrictions on the development of tourism and recreation, it is advisable to implement measures to minimize the impact of pandemic risks through specially designed programs to support economic, including tourism and recreation, both at the state level and at regional or micro level.

Keywords: tourist and recreational complex, sustainable growth, tourism, recreational potential, national economy.

Постановка проблеми. Одним із досить привабливих видів економічної діяльності $€$ туристично-рекреаційний комплекс. Цей комплекс є також складовою забезпечення стабільного та динамічного зростання економіки, адже багато надходжень від такої діяльності надходять до державного бюджету. Туристично-рекреаційний комплекс - це складова забезпечення розвитку інших видів економічної діяльності. Завдяки цьому виду діяльності створюються нові робочі місця i, тим самим, підвищується рівень зайнятості населення, рівень трудової активності населення, рівень благополуччя суспільства.

Під впливом реалізації цілей світової стратегії зростання економіки змінюються парадигми розвитку туристично-рекреаційного комплексу. Такі зміни спонукають учасників туристичнорекреаційного комплексу поступово переорієнтовуватись на засади сталого розвитку.

Доцільно зауважити, що в умовах сьогодення індустрія туризму та рекреації зазнала значного негативного впливу через наслідки, спричинені пандемією COVID-19. В результаті такого впливу відбулося зниження рівня есрективності фрункціонування суб'єктів туристичної та рекреаційної діяльності, що негативно позначилось на шляху до сталого зростання економіки.
Аналіз останніх досліджень і публікацій. Проблематику розвитку туристичнорекреаційного комплексу як складову сталого зростання економіки досліджує А. Алієва [1], К. Горб [2], М. Корнієв [2], М. Куржова [2], А. Огієнко [3], М. Огієнко [3], Ю. Петровича [4], Л. Прокопишин Рашкевич [4], Б. Шадурська [4] та інші.

Зокрема А. Алієва [1] зазначає, що туристично-рекреаційний комплекс - це складова частина національної економіки, роль функціонування якої полягає у забезпеченні виробництва і реалізації соціально корисної продукції, об'єктом якоїє туристично-рекреаційні послуги. За дослідженнями науковця суб'єктами туристично-рекреаційного комплексу є суб'єкти, що надають туристичні і рекреаційні послуги, населення та громади, органи державної влади та органи місцевого самоврядування, міжнародні організації. Особливого значення для активізації розвитку туристично-рекреаційних послуг на міжнародному ринку набуває застосування кластерних моделей для підвищення рівня організованості діяльності суб'єктів туристично-рекреаційної діяльності.

В основі фрункціонування туристично-рекреаційного комплексу лежить туристичний та рекреаційний потенціал. Науковці А. Огієнко та М. Огієнко [3] зазначають, що рекреацій- 
ний потенціал - це комплекс рекреаційних ресурсів, які можна використовувати на певній території (такі ресурси найчастіше використовуються для відпочинку). Своєю чергою, туристичний потенціал відображає приналежність до туристичної сорери. Науковці стверджують, що рекреаційний потенціал впливає на відновлення людського ресурсу в процесі відпочинку.

Колектив науковців під керівництвом М. Корнєєва [2] наголошує, що туристична індустрія - це один із чинників соціально-економічного розвитку багатьох регіонів та країн. У багатьох країнах, внесок туризму у ВВП $\epsilon$ досить великим, що позитивно впливає на економіку загалом. Сорера туризму відіграє важливу роль у розвитку економіки України. Науковці стверджують, що Європейський Союз $є$ важливим партнером нашої країни у різних сорерах, зокрема у сорері туризму багато туристів 3 країн ЄС і не тільки приїжджає до нашої країни, щоб побачити пам'ятки, а також відвідати унікальні історичні об'єкти.

Л. Прокопишин-Рашкевич, Б. Шадурська та Ю. Петровича [4] зауважують, що найбільш перспективними видами туристичної діяльності в Україні $є:$ a) рекреаційний туризм; б) лікувальний туризм; в) екотуризм; г) діловий туризм. Виходячи із досліджень науковців, доцільно відзначити те, що Україна має особливу привабливість серед туристів у сорері медичного туризму. Цьому слугують низькі ціни, належна якість медичних ліків, доступність медичної допомоги та високий рівень профресіоналізму фрахівців медичної сфрери. В умовах сьогодення в Україні стрімко розвивається ще такий досить новий та вже перспективний вид туризму як бізнес-туризм, завдяки якому доходи від туристичної діяльності стрімко зростають та відповідно збільшують частку находжень цього виду економічної діяльності у ВВП.

Виділення невирішених раніше частин загальної проблеми. Акцентуючи увагу на проблемах важливості розвитку туристичнорекреаційного комплексу, доцільно зауважити те, що не до кінця розкритими є питання розвитку туристично-рекреаційного комплексу в умовах сталого зростання економіки.

Формулювання цілей статті (постановка завдання). Метою наукової статті $€$ дослідження особливостей розвитку туристичнорекреаційного комплексу в умовах сталого зростання економіки України.

Виклад основного матеріалу дослідження. Україна переповнена великою кількістю як широко відомих, так і зовсім невідомих, але при цьому надзвичайної краси туристичних об'єктів. Країни з економікою, що розвиваються, пропонують більші пропозиції мандрівникам і стають все більш популярними як туристичні напрямки. Маючи сім визначних пам'яток, які входять до Світової спадщини ЮНЕСКО, Україна володіє численними історичними, культурними та рекреаційними ресурсами, що відкриває значні можливості в туристично-рекреаційній сорері.

Обсяги находжень від подорожей та туризму в економіку України 3 кожним роком зростають. Так, наприклад, в період 2015-2019 років відбулося тенденційне зростання цього показника, де у 2019 році проти 2015 року обсяг надходжень від подорожей та туризму в економіку України зріс у два рази (рис. 1). Однак під впливом пандемічних обмежень, які охопили цілий світ, туристична індустрія в 2020 році дещо занепала. Так, у 2020 році находження від подорожей та туризму в економіку України у порівнянні із 2019 роком скоротилися на 2,3 млрд. дол. США.

У відповідності до зростання надходжень від подорожей та туризму в економіку України збільшується частка цього виду економічної діяльності у ВВП. Так, в період 20152019 років частка цього виду економічної діяльності у ВВП тенденційно зростала від 5,7 \% у 20152016 роках до 6,8 \% - у 2019 році (рис. 2). Як зазначалось вище, зниження надходжень від подорожей та туризму в економіку України у 2020 році у порівнянні із 2019 роком призвело до скорочення частки цього виду економічної діяльності на 1,6 \%.

Доцільно зауважити, що внесок туристичнорекреаційного комплексу у ВВП у достатній мірі обумовлений розробкою та реалізацією на практиці державних програм, які спрямовані на створення сприятливих умов для розвитку сорери туризму і рекреації. Так, наприклад, завдяки таким програмам, які успішно були реалізовані у країнах Західної Європи та США, розвиток туристично-рекреаційного комплексу був досить ефективним. Основним регулятором забезпечення такого розвитку стали ринкові відносини, завдяки яким ці країни здійснюють економічний прорив. Враховуючи зазначене вище, доцільно стверджувати, що розвиток туристично-рекреаційного комплексу не може бути ефективним, якщо він не регулюється відповідно призначеними для цього державними інструментами та не забезпечується державною підтримкою. Саме реалізація таких дій дасть змогу забезпечити сприятливі умови для розвитку сорери туризму і рекреації, а також визначити пріоритетні напрями, ініціювати та розробити концепції 


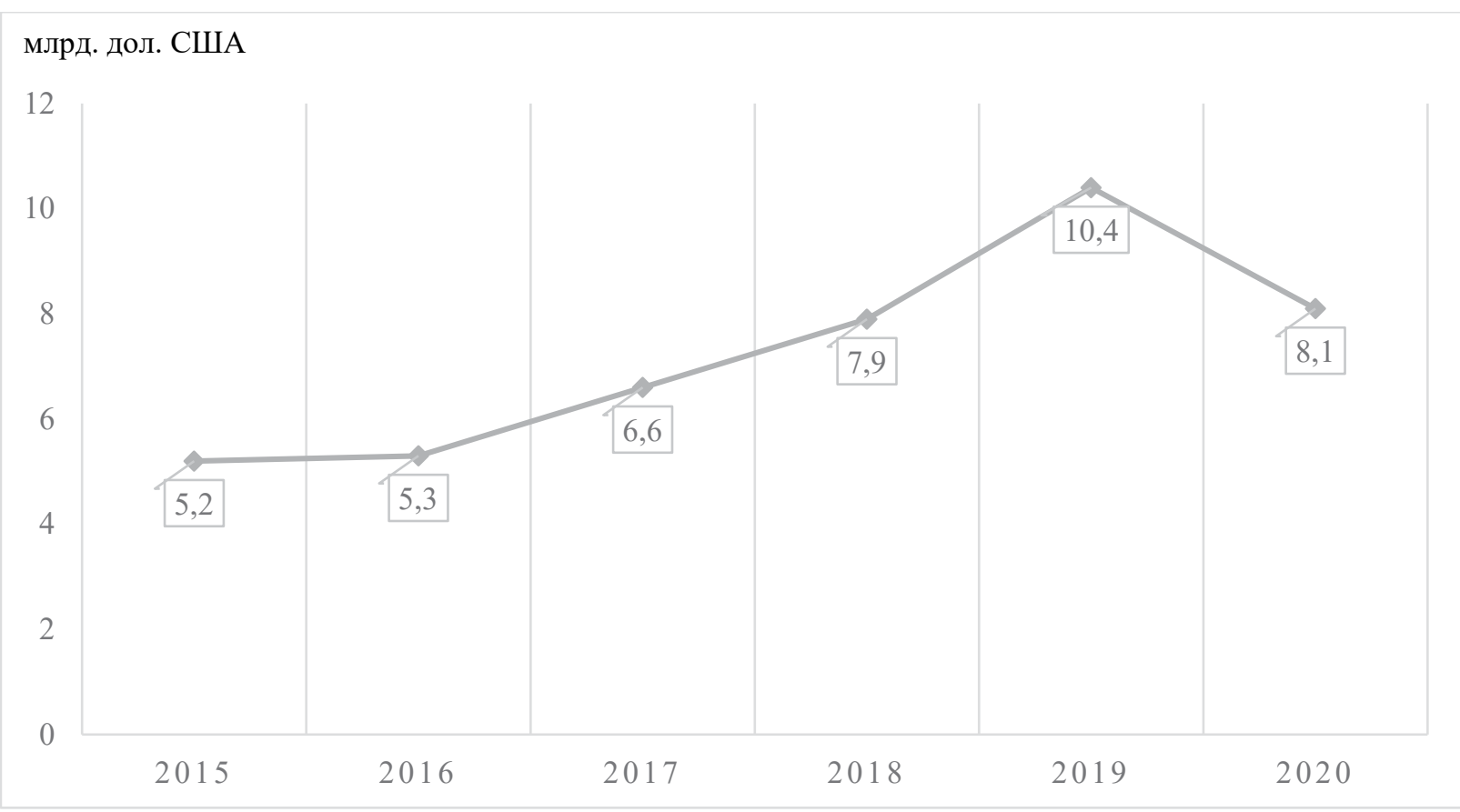

Рис. 1. Динаміка надходжень від подорожей та туризму в економіку України Джерело: побудовано авторами за даними [5]

та програми розвитку сорери туризму і рекреації у контексті їх срінансового, кадрового, правового та інфрормаційного забезпечення.

Акцентуючи увагу на таких засадах, виникає необхідність у розкритті особливостей фрінансування розвитку сорери туризму в Україні. Так, динаміка залучення капітальних інвестицій у розвиток туристичної сорери є вкрай нестабіль- ною, що пояснюється нестабільністю фрінансового забезпечення цього виду економічної діяльності. В період 2017-2020 років туристичними агентствами та туристичними операторами найбільше було освоєно капітальних інвестицій у 2017 році (80070 тис. грн). У наступні роки обсяг освоєних капітальних інвестицій то скорочувався, то знову зростав і у 2020 році у порів-

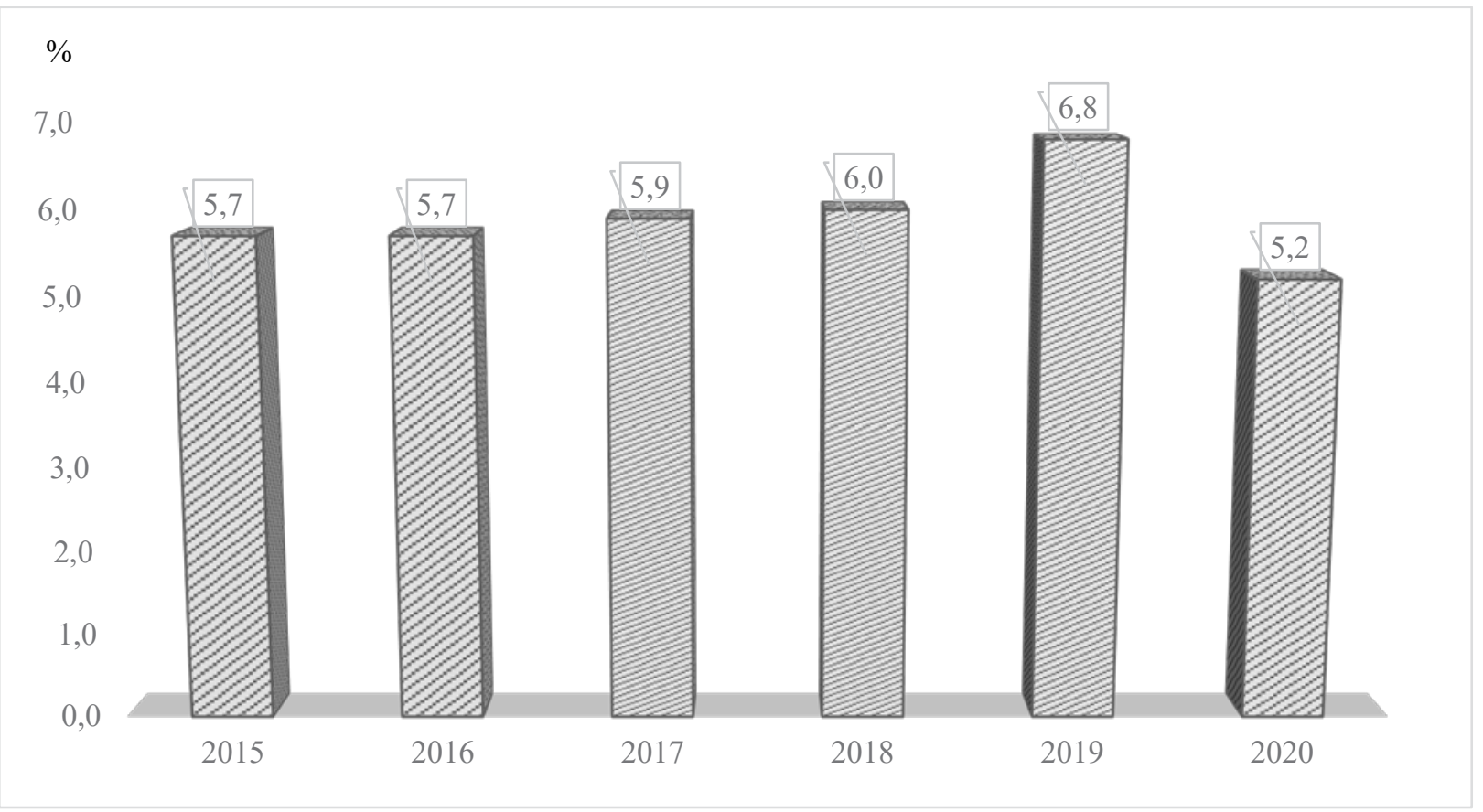

Рис. 2. Питома вага надходжень від подорожей та туризму у ВВП України Джерело: побудовано авторами за даними [5; 6] 
Капітальні інвестиції у туристичну діяльність в Україні

Таблиця 1

(на прикладі діяльності туристичних агентств та туристичних операторів)

\begin{tabular}{|l|c|c|c|c|}
\hline \multicolumn{1}{|c|}{ Індикатори } & $\mathbf{2 0 1 7}$ & $\mathbf{2 0 1 8}$ & $\mathbf{2 0 1 9}$ & $\mathbf{2 0 2 0}$ \\
\hline $\begin{array}{l}\text { Освоєно (використано) капітальних } \\
\text { iнвестицій, тис. грн. }\end{array}$ & $\mathbf{8 0 0 7 0}$ & $\mathbf{3 6 4 7 9}$ & $\mathbf{5 4 0 0 0}$ & $\mathbf{3 1 4 3 0}$ \\
\hline зокрема: & \multicolumn{4}{|l|}{} \\
\hline у\% загального обсягу капітальних інвестицій & 0,019 & 0,007 & 0,009 & 0,007 \\
\hline у \% до попереднього року & 187,4 & 52,5 & 143,4 & 58,2 \\
\hline
\end{tabular}

Джерело: розраховано авторами за даними Державної служби статистики України [7]

нянні із показниками за досліджуваний період був найнижчим (31430 тис. грн) (табл. 1). Тенденцію падіння обсягу капітальних інвестицій у діяльність туристичних агентств та туристичних операторів у 2020 році можна пояснити ситуацією, яка виникла на тлі пандемічних обмежень, спричинених COVID-19.

Нестабільна динаміка зміни капіталовкладень у туристичну сореру призвела до зміни частки цих капіталовкладень у загальному обсязі капітальних інвестицій, що були спрямовані у всі види економічної діяльності. Так, найнижчою частка капітальних інвестицій у сореру туризму від загального обсягу капітальних інвестицій, якими інвестувалися всі види економічної діяльності в Україні, була за 2018 та 2020 роки та становила 0,009 \% відповідно.

У ході дослідження особливостей розвитку рекреаційної ссрери в Україні особливу увагу доцільно зосередити на розвитку колективних засобів розміщування. Так, в період 2017-2019 років кількість колективних засобів розміщування тенденційно зростала, однак за 2020 рік відбулося скорочення на 812 одиниць, порівняно із попереднім роком, наслідком чого знову ж таки стали пандемічні обмеження, які охопили не тільки Україну, але і цілий світ (табл. 2).

Динаміка кількості місць у колективних засобах розміщування в період 2017-2020 років була також нестабільною. Після падіння у 2018 році на 59,0 тис. одиниць місць, кількість місць у 2019 році зросла на 70,6 тис. одиниць, а у 2020 році знову скоротилась, при чому зниження становило 58,5 тис. одиниць. У 2020 році у порівнянні із попереднім роком на 105,8 \% скоротилася кількість осіб, що перебували у колективних закладах розміщування. Що стосується іноземців, які перебували у колективних закладах розміщування, то тут тенденція $€$ ще більш негативною, оскільки за 2020 рік, порівняно із 2019 роком, темп скорочення цього показника становив 277,1\%.

Висновки. Таким чином, за результатами проведених досліджень встановлено, що туристично-рекреаційний комплекс - це один із ключових видів економічної діяльності в Україні, без якої не можливий сталий розвиток національної економіки. Доцільно зазначити, що за досліджувані 2015-2020 роки динаміка розви-

Таблиця 2

Колективні засоби розміщування

\begin{tabular}{|l|c|c|c|c|}
\hline \multicolumn{1}{|c|}{ Індикатори } & $\mathbf{2 0 1 7}$ & $\mathbf{2 0 1 8}$ & $\mathbf{2 0 1 9}$ & $\mathbf{2 0 2 0}$ \\
\hline $\begin{array}{l}\text { Кількість колективних засобів } \\
\text { розміщування, од. }\end{array}$ & $\mathbf{4 1 1 5}$ & $\mathbf{4 7 1 9}$ & $\mathbf{5 3 3 5}$ & $\mathbf{4 5 2 3}$ \\
\hline 3 них у \% до попереднього року & 96,7 & 114,7 & 113,1 & 84,8 \\
\hline $\begin{array}{l}\text { Кількість місць у колективних } \\
\text { засобах розміщування, тис. од. }\end{array}$ & $\mathbf{3 5 9 , 0}$ & $\mathbf{3 0 0 , 0}$ & $\mathbf{3 7 0 , 6}$ & $\mathbf{3 1 2 , 1}$ \\
\hline 3 них у \% до попереднього року & 95,6 & 83,6 & 123,5 & 84,2 \\
\hline $\begin{array}{l}\text { Кількість осіб, що перебували } \\
\text { у колективних засобах } \\
\text { розміщування, тис. осіб }\end{array}$ & $\mathbf{6 6 6 1 , 2}$ & $\mathbf{7 0 0 6 , 2}$ & $\mathbf{6 9 6 0 , 9}$ & $\mathbf{3 3 7 9 , 5}$ \\
\hline 3 них у до попереднього року & 101,8 & 105,2 & 99,4 & 48,5 \\
\hline $\begin{array}{l}\text { Кількість іноземців, що } \\
\text { перебували у колективних } \\
\text { засобах розміщування, тис. осіб }\end{array}$ & $\mathbf{8 2 4 , 5}$ & $\mathbf{9 1 7 , 9}$ & $\mathbf{9 5 9 , 4}$ & $\mathbf{2 5 4 , 4}$ \\
\hline 3 них у \% до попереднього року & 95,5 & 111,3 & 104,5 & 26,5 \\
\hline
\end{tabular}

Джерело: розраховано авторами за даними Державної служби статистики України [8] 
тку туристично-рекреаційного комплексу була вкрай нестабільною, а особливо в останній рік. Пандемічні обмеження, спричинені COVID-19, негативно позначились на показниках розвитку туристично-рекреаційного комплексу України. Так, у 2020 році у порівнянні із попередніми роками, а особливо із 2019 роком, суттєво скоротились - надходження від подорожей та туризму в національну економіку, i, як наслідок, знизилася частка надходжень від подорожей та туризму у ВВП України. Пандемічні обмеження також негативно позначились на залученні капітальних інвестицій у розвиток туристичної діяльності в Україні, а також на стан діяльності колективних засобів розміщування. Акцентуючи увагу на таких негативних наслідках, доцільно зауважити про наявність певного негативного впливу, якого зазнала національна економіка від туристичнорекреаційної діяльності. Тому, з метою зниження наслідків пандемічних обмежень на розвиток туристично-рекреаційного комплексу доцільно впроваджувати заходи мінімізації впливу пандемічних ризиків через спеціально розроблені програми підтримки видів економічної, зокрема туристично-рекреаційної діяльності, як на рівні держави, так і на рівні регіонів чи мікрорівні.

\section{СПИСОК ВИКОРИСТАНИХ ДЖЕРЕЛ:}

1. Алієва А.Ю. Організаційно-економічні засади сталого розвитку туристично-рекреаційної сфери в Україні : дис. на здобуття наук. ступ. к. екон. наук. 08.00.03. Волинський національний університет імені Лесі Українки, Луцьк : Національний університет водного господарства та природокористування. Рівне, 2021. 225 с.

2. Kornieiev M., Horb K., Kurzova M. Development of the Ukrainian Tourism Industry in the Context of Integration to the EU. Східна Європа: економіка, бізнес та управління. 2019. Випуск 2(19). С. 21-26.

3. Огієнко А.В., Огієнко М.М. Теоретичні засади дослідження туристично-рекреаційного потенціалу. Проблеми системного підходу в економіці. 2020. Вип. 1(1). С. 31-37.

4. Прокопишин-Рашкевич Л., Шадурська Б., Петровича Ю. Індустрія туризму в Україні: перспективні напрямки та виклики сучасності. Вісник Національного університету «Львівська політехніка». Серія «Проблеми економіки та управління». 2020. Том 4. № 1. С. 72-82.

5. Driving the Tourism Recovery in Ukraine. Data and Digital Platforms. URL: https://s3.amazonaws.com/ tourism-economics/craft/Google_Ukraine_Final.pdf

6. Валовий внутрішній продукт (у фрактичних цінах). Державна служба статистики України. URL: http://www.ukrstat.gov.ua/

7. Капітальні інвестиції. Державна служба статистики України. URL: http://www.ukrstat.gov.ua/

8. Колективні засоби розміщування (2011-2020). Державна служба статистики України. URL: http://www.ukrstat.gov.ua/

\section{REFERENCES:}

1. Alijeva, A.Ju. (2021) Orghanizacijno-ekonomichni zasady stalogho rozvytku turystychno-rekreacijnoji sfery v Ukrajini: dys. na zdobuttja nauk. stup. k. ekon. nauk 08.00.03. Volynsjkyj nacionaljnyj universytet imeni Lesi Ukrajinky, Lucjk; Nacionaljnyj universytet vodnogho ghospodarstva ta pryrodokorystuvannja. Rivne, 225 p. (in Ukrainian)

2. Kornieiev, M., Horb, K., Kurzova, M. (2019) Development of the Ukrainian Tourism Industry in the Context of Integration to the EU [Development of the Ukrainian Tourism Industry in the Context of Integration to the EU]. Skhidna Jevropa: ekonomika, biznes ta upravlinnja - Eastern Europe: Economy, Business and Management, 2(19), 21-26. (in Ukrainian)

3. Oghijenko, A.V., Oghijenko, M.M. (2020) Teoretychni zasady doslidzhennja turystychno-rekreacijnogho potencialu [Theoretical principles of research of tourist and recreational potential]. Problemy systemnogho pidkhodu $v$ ekonomici - Problems of system approach in economics, 1(1), 31-37. (in Ukrainian)

4. Prokopyshyn-Rashkevych, L., Shadursjka, B., Petrovycha, Ju. (2020) Industrija turyzmu v Ukrajini: perspektyvni naprjamky ta vyklyky suchasnosti [Tourism industry in Ukraine: promising areas and challenges of today]. Visnyk Nacionaljnogho universytetu "Ljvivsjka politekhnika». Serija «Problemy ekonomiky ta upravlinnja» - Bulletin of the National University "Lviv Polytechnic". Series "Problems of Economics and Management", 4(1), 72-82. (in Ukrainian)

5. Driving the Tourism Recovery in Ukraine. Data and Digital Platforms. Retrieved from: https://s3.amazonaws.com/ tourism-economics/craft/Google_Ukraine_Final.pdf (in Ukrainian)

6. Valovyj vnutrishnij produkt (u faktychnykh cinakh). Derzhavna sluzhba statystyky Ukrajiny. Retrieved from: http://www.ukrstat.gov.ual (in Ukrainian)

7. Kapitaljni investyciji. Derzhavna sluzhba statystyky Ukrajiny. Retrieved from: http://www.ukrstat.gov.ual (in Ukrainian)

8. Kolektyvni zasoby rozmishhuvannja (2011-2020). Derzhavna sluzhba statystyky Ukrajiny. Retrieved from: http://www.ukrstat.gov.ua/ (in Ukrainian) 